\title{
The Impact of Place Attachment of Historical Neighborhood Residents On the Tourism Support
}

\author{
Tarihi Mahalle Sakinlerinin Yere Bağıılığının Turizm Desteği Üzerindeki Etkisi
}

\author{
Aslı ALTANLAR
}

This article studies the relationship between the place attachment of historical neighborhood residents, the effects of tourism, and the support for tourism. The study was conducted in ten historical neighborhoods in Central Amasya, which are the best examples of Turkish civil architecture of small squares, Islamic-Ottoman social complexes, and mosques. Total sample number for 3336 houses was determined as 345. The questionnaires were applied between October and December 2017 on weekdays and weekends alike with simple random sampling method. A total of 460 houses agreed to answer the questionnaire. Principal components analysis was applied to determine the construct validity of place attachment and tourism effects scales. In order to discover the relationship between the place attachment scale of the participants and perceived effects of tourism \& the support for tourism scales, Spearman's correlation test is applied as nonparametric test method. According to the study results, it was determined that place-based sense of belonging and social attachment had an influence on the residents' perception of and approach towards tourism. It is seen that neighborhood residents were in agreement that tourism would have positive effects on the neighborhood and that they did not develop any concerns about any negative effects of tourism. Similarly, it is understood that the more place attachment neighborhood residents had, the more supportive they were of any touristic endeavors. This indicates that any negative developments that may arise with functional changes that comes with touristic endeavors might cause a negative impact on their approach to and support of tourism.

Keywords: Belonging; effects of tourism; place attachment; support for tourism; tourism planning.

Bu çalışma, mahalle sakinlerinin yer aidiyeti, turizm etkileri ve turizm desteği arasındaki ilişkiyi incelemektedir. Çalışma, Türk sivil mimarisinin örneklerini yansıtan, küçük meydanlar, külliye ve camileri bünyesinde barındıran Amasya ili Merkez ilçesindeki on adet tarihi mahallede yapılmıştır. Toplam örneklem sayısı 3336 hane için 345 olarak belirlenmiştir. Anketler Kasım ve Aralık 2017 tarihleri arasında hafta içi ve hafta sonu dahil olmak üzere basit tesadüfi örnekleme yöntemi kullanılarak uygulanmıştır. Bu süreç içerisinde ankete toplam 460 hane cevap vermeyi kabul etmiştir. Yere bağıılık ve turizmin etkileri ölçeğinin yapı geçerliliğinin belirlenmesi amacıyla temel bileşenler analizi uygulanmıştır. Katılımcıların yere bağlılık ölçeği ile turizmin algılanan etkileri ve turizm desteği ölçeği arasındaki ilişkiyi keşfetmek için ise parametrik olmayan test tekniklerinden Spearman korelasyon testi uygulanmıştır. Araştırma sonuçlarına göre yer temelli aidiyet ve sosyal bağıı̆ı̆ın yerin sakinlerinin turizme yönelik algı ve tutumlarında etkili olduğu tespit edilmiştir. Mahalle sakinlerinin turizmin mahalleye pozitif etkiler getireceği konusunda hemfikir oldukları ve aynı zamanda turizmin sebep olabileceği negatif etkiler konusunda henüz endişe hissetmedikleri görülmektedir. Benzer bir şekilde mahalle sakinlerinin yere bağlılıkları arttıkça yereli desteklemeyi amaçlayan turistik girişim türlerini destekleme durumlarının arttı̆ı̆ anlaşılmaktadır. Bu durum söz konusu turistik girişim türleri ile ilgili meydana gelebilecek fonksiyon değişikliklerinden kaynaklanabilecek olumsuz etkilerin turizme karşı tutum ve desteklerini de negatif yönde etkileyeceğini ortaya koymaktadır.

Anahtar sözcükler: Aidiyet; turizm etkileri; yere bağlıık; turizm desteği; turizm planlaması.

Department of Urban and Regional Planning, Amasya University Faculty of Architecture, Amasya, Turkey

Article arrival date: December 16, 2020 - Accepted for publication: March 04, 2021

Correspondence: Aslı ALTANLAR. e-mail: asli.altanlar@gmail.com

○ 2021 Yıldız Teknik Üniversitesi Mimarlık Fakültesi - ๑ 2021 Yıldız Technical University, Faculty of Architecture 


\section{Introduction}

With the world-wide rise of neo-liberalism, the tourism industry started to feature "change" by commoditizing touristic regions and places through discourses like investment, competitiveness, and entrepreneurship. The desire of cities and regions to self-differentiate from others in the globalizing world brought together many strategies based on perception and identity (Bolzoni, 2013, p. 2; Kunzmann, 2004, p. 386). These strategies were mainly focused on entertainment and consumption, and they aim to make everything a "consumable", including all tangible and intangible cultural heritage elements as well as goods and services. Interventions within this framework including the renewal of an already-built environment, its re-construction, alteration in functions, and revitalization of collapsing and deserted areas may result in changes and gentrification of local features (Bolzoni, 2014, p. 11). These aspects of tourism not only change the physical environment but also change (or at least influence) the meaning attached to a place. Commercialization of historical and cultural values may cause the intangible values attached to a space be replaced with tangible values or may even cause the sentimental values like neighborhood, friendship, and hospitality be replaced with economic interests. This over-commercialization of a space may result in every value in a touristic area be seen as an "income channel", causing a negative impact on or even the loss of historical and cultural values in the region (Kozak, Kozak, \& Kozak, 2013, p. 92). For this reason, as much as it is not meaningful to perceive the development of tourism as an intervention that eliminates many problems in economic, social, and environmental issues, on which central and local administrations cannot agree, it is also a false approach to perceive it as a scapegoat that will inevitably damage social and physical environment (Huning \& Novy, 2006, p. 15). On one hand, tourism creates a sense of toleration between residents, users, and tourists through mutual communication; on the other hand, it may improve the interaction and connections between local actors through increasing environmental awareness of residents. But when the tourism industry exploits the relationship between residents and tourists, it may cause conflicts and tension (Huning \& Novy, 2006, p. 10). Therefore, countries adopt sustainable tourism policies to minimize the aforementioned negative effects of tourism development, to preserve and improve historical and natural environment, improve the quality of life of residents by creating economic values for the region and the community, and to ensure higher quality experiences for visitors. According to McCool and Martin (1994, p.29), the place attachment experienced by residents is an important element in their satisfaction of life and their approach towards tourism. Similarly, Um and Crompton (1987) underlines that the level of place attachment of residents create differences in their approaches towards tourism (Interpreted from Um and Crompton, 1987 by Arslan Ayazlar \& Ayazlar, 2016, p. 1453). There are many studies in the literature conducted on the effect of tourism development on residents. However, there is a limited number of studies aiming to discover the relationship between the place attachment of residents and the perceived effects of tourism (Arslan Ayazlar \& Ayazlar, 2016; Hallak, Brown, \& Lindsay, 2012; Ginting \& Wahid, 2016; Stylidis, 2018; Wang \& Xu, 2015, Altanlar, 2015, Buzukçu, 2020). Therefore, this study aims to determine the effects of place attachment of residents living in historical neighborhoods, which are touristic attractions, on their approach towards the effects of tourism and the support for it. In this study, place attachment was regarded as an umbrella-concept that includes all manners of human and place relationship, considering the affective relations a person forms with a place. Tourism's effects are discussed in both positive and negative aspects in terms of economic, socio-cultural and environmental levels. The support towards the development of tourism is discussed in terms of strategies and entrepreneurship tendency within the framework of local touristic ventures and tendencies. These touristic ventures comprise of policies and strategies that will enable the maximum benefit for a touristic region through adding value to natural, economic, and socio-cultural elements while also focusing on the values, capacities, and needs of the residents (Figure 1).

The main goal of the study was determined as to discover how effective is the place attachment of residents

Personal Features

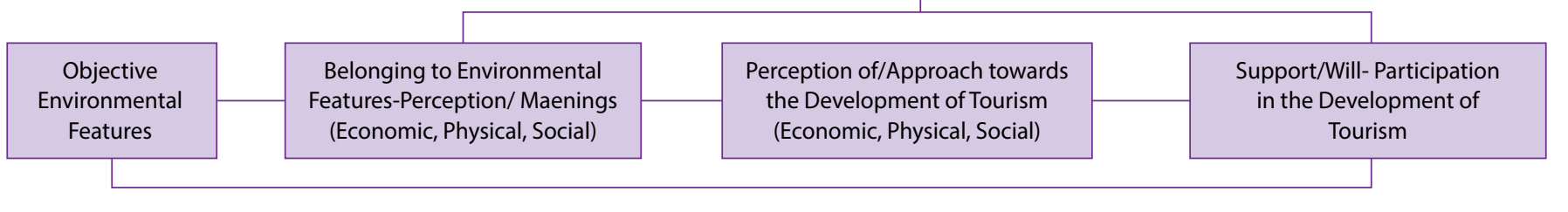

Figure 1. The relationship between place attachment and approach towards tourism's effects \& the support for tourism. 
on their approach towards the effects and development of tourism. This main question also looks for the answers of the below sub-questions:

- Is there a relationship between the place attachment of residents and their perception of tourism's effects? If yes, what is the direction and level of such a relationship?

- Is there a relationship between the place attachment of residents and their support for tourism? If yes, what is the direction and level of such a relationship?

- Is there a relationship between the place attachment of residents and their tendencies towards touristic ventures? If yes, what is the direction and level of such a relationship?

Various Concepts on Human-Environment-Tourism

Relationships within the Framework of Place

Attachment

It is possible to trace the communal living and obtain information about what was vital through a place. With these features, places ensure that the sense of community is formed and the social relationship flows are sustained (Aytaç, 2013, p. 155). Therefore, in order to fully comprehend the meaning flow of a place, the continuous interaction process between individuals and their physical \& social environments must be understood (Y.Imaz Çakmak, 2013, p. 55). Individuals form stronger attachments with a place, in which they can define themselves and that they are proud to be a part of. The interactions individuals form with a place and others residing in the same place enable individuals to know the houses, parks, and shops forming the physical texture of a place and help them attribute meanings to these locations, which in return strengthen the sense of belonging (Brown, Perkins, \& Brown, 2003, p. 261). Within that framework, the sense of belonging means a positive and effective connection between the individual and the place. An individual who feels like he/she belongs to a place forms and sustains close relationships with that place. In fact, the place can become a symbol of an individual's identity, based on the strength of that connection (Hidalgo \& Hernandez, 2001, p. 274).

The previous studies on place attachment haven't yet met on common grounds about how to methodologically define this fact. Consequently, "attachment to community", "place identity", and "place attachment" may become intersecting concepts in fieldworks (Hernandeza, Hidalgo, Salazar-Laplace, \& Hes, 2007, p. 311). For example, place attachmentcan bedefinedas"strongemotional connections individuals feel towards a place or region". Proshansky, Fabian and Kaminoff (1983) define "place identity" as "a complicated pattern that contains a combination of the identity of place and individual within its structure and that is determined by the preferences, expectations, emotions, values, and beliefs people have in their relationships with natural and structured environment, physical world, and other people (Interpreted from Proshansky and Ark., 1983 by Buzukçu, 2020, p. 3). Rollero and Piccoli (2010, p.198-199) refer to "place attachment" as an emotional connection between man and place while defining "place identity" as the cognition of "self" stemmed from being a member of a physical place. Place identity can also be defined as a sub-culture for a group of people explaining their lives based on a physical environment (Ginting \& Wahid, 2016, p. 45-46). It is possible for an individual to not feel like a place is a part of his/her identity, despite the affective connection he/she has formed with the place, or he/she may not prefer to live in an area, despite defining his/her identity based on that place. Therefore, there are some views stating that defining an affective connection as place identity might be misleading (Hernandeza, Hidalgo, Salazar-Laplace, \& Hes, 2007, p. 311).

Place attachment is formed from the meanings (fear, trauma, happiness, pleasure, etc.) an individual or a community attributes to a place resulting from their experiences of physical and social environment with the impact of their perception, belief, point of view, and ideas ( (Kyle, Graefe, Manning, \& Bacon, 2014, p. 153-154; Yoon, 2002; Brown, Perkins, \& Brown, 2003, p. 259). Therefore, place attachment means "the level of value individuals attribute to a place, the strong association between individuals and the place, and the feelings and emotional and/or symbolical association of an individual and the place" (Vorkin \& Reise, 2001, p. 249-250). Shumaker and Taylor (1983) define place attachment as a positive and effective connection or relationship between individuals and their residencies (Interpreted from Shumaker and Taylor, 1983 by Hidalgo and Hernandez, 2001, p.274). Various studies on the subject unanimously indicate that place attachment have functions like meeting the needs of self-expression, transmission, predictability, and control of individuals and the need to create an identity on individual, group, community, and cultural levels (Interpreted from Low and Altman, 1992 by Göregenli, 2010, p. 180) while also supporting to create and sustain the individual needs like stability, safety, and control (Lewicka, 2008, p. 211). If individuals cannot form an environment of domination around themselves, they cannot feel safe or like they belong to that place. Individuals who cannot form an environment of domination cannot also create an area of privacy and thus, they cannot feel comfortable in their surroundings (Ilgın \& Hacıhasanoğlu, 2006, p. 62). Lewisca (2008, p. 211) focuses on the affective connections created from an interaction with place and expresses that place attachment plays an important role in the development of individual, group, and cultural self-esteem, self-worth, and self-praise feelings. In fact, place attachment can even be a defense 
against identity crises that may arise in transitional periods between successive developmental stages (Lewicka, 2005, p. 382). McGuire (1997) determined that the sense of place attachment in individuals who live in "irregular" and "old" neighborhoods decrease over time (Interpreted from McGuire, 1997 by Brown, Perkins, \& Brown, 2003, p. 261). On the other hand, Brown et al. (2003, p. 261) also indicated in their study that the connections between individuals and neighborhood tends to decrease over time, if the individuals feel unsafe and are scared of any criminal activities (Brown, Perkins, \& Brown, 2003, p. 261). In other words, places are preserved and used only as much as they are embraced and the more they are preserved and used, the more individuals feel attachment and belonging. In that case, attachment can contribute to preserving and sustaining the identity of a place (Lewicka, 2005, p. 382; Brown, Perkinds, \& Brown, 2004, p. 361). To put it in a different way, the strong connection an individual feels towards a place may encourage that individual to adopt ecological behaviors for that place or to take part in civil activities to prevent any harm to come that place or to stand against a similar approach (Lewicka, 2005, s. 382; Brown, Perkinds, \& Brown, 2004, p. 361).

"Community attachment" is another concept that must be mentioned in the literature on place attachment. Community attachment is a multidimensional concept that contains connections with social, economic, political, and physical environment as well as the symbolical meanings that express the social participation of an individual in the community. For this reason, it is not possible to discuss "community attachment" independently from "place attachment", where individuals interact with each other and form social connections. From that point of view, community attachment contains place attachment and place identity concepts within its framework (Buzukçu, 2020 , p. 34). As a result, when the literature on this subject is examined thoroughly, it is understood that the theory of place attachment can be discussed in five categories: attachment elements (affectivity, cognition, and activity); spaces/places with different scales and features; different actors (individuals, group, community, and cultures); different social relationships (individuals, group, community, and cultures); and temporal indications (linear and cyclical) (Göregenli, 2010, p. 180).

The Relationship between Place Attachment and Approach Towards the Development of Tourism \& the Support for Tourism

There is a limited number of studies researching the effect of place attachment residents living in touristic areas feel towards a place on their approach towards tourism's effects (Altanlar, 2015; Arslan Ayazlar \& Ayazlar, 2016; Buzukçu, 2020; Hallak, Brown, \& Lindsay, 2012; Ginting \&
Wahid, 2016; Stylidis, 2018; Wang \& Xu, 2015). However, these studies have contradicting results about the effects of place attachment on tourism. For example, Um and Crompton (1987) revealed that the higher place attachment levels are, the more negative residents perceive tourism, whereas Jurowski (1994) revealed that tourism's perceived effects tend to be positive with regards to economic and social effects and negative with regards to environmental effects (Um and Crompton, 198 and Interpreted from Jurowski, 1994 by Arslan Ayazlar \& Ayazlar, 2016, p. 1456). Buzukçu (2020) indicates that the changes caused by tourism and following activities have positive effects on the perception of place identity and community attachment but have meaningfully negative effects on the support for tourism (Buzukçu, 2020, p. 148-149).

Wang and Chen (2015) determined that selfrespect, self-sufficiency, continuity, and the feeling of identification, which are the components of place identity have a significant impact on the perception and approach of residents towards tourism whereas the duration of residency in that area defines the strength of the relationship between place identity and approach (Wang \& Chen, 2015, p. 23). Choi and Murray (2010) state that there is a linear relationship between the place attachment of residents and their perception of tourism's effects (Choi \& Murray, 2010, p. 588). Arslan, Ayazlar and Ayazlar (2016, p.1464), express that the feeling of place attachment is effective in the perception of negative effects as is they were positive. The study indicates that the feeling of "belonging" has the strongest impact on the perception of economic effects of tourism. Furthermore, it also proves that the community's feeling of belonging is effective in the public perceiving negative environmental effects of tourism as if they were positive.

Hallak, Brown and Lindsay (2012) set forth that place identity and place attachment have positive effects on the entrepreneurship performances of business owners in tourism industry based on entrepreneurship and environmental psychology literature. In other words, the feeling of identity a tourism entrepreneur receives from the place contributes to the success of his/her venture (Hallak, Brown, \& Lindsay, 2012, p. 150-151). Stylidis (2018, p.8) determined that place attachment and the perceived image of the place have positive effects on the residents' perception of tourism's effects and their support for tourism. In contradiction with its predecessors focusing on place attachment, the aforementioned study enabled the place and place attachment to be discussed as a concept while determining the reactions of residents against tourism (Stylidis, 2018, p. 13). In their study researching the relationship between place identity \& place attachment and the possibility of illegal environmental actions and 
environmental approach towards social norms, Hernandez, Martin, Ruiz and Hidalgo (2010) determined that place identity and place attachment have no direct effect on personal norms. Despite that, they also determined that place identity affected environmental approach and social norms, which are the leading elements of personal norms (Hernandez, Martin, Ruiz, \& Hidalgo, 2010, p. 285-286). Wang \& Xu ( 2015, p. 247) determined that individuals with a higher sense of place identity and community attachment are more concerned regarding the negative effects of tourism. Similarly, there are also some studies revealing the relationship between community attachment and tourism. These studies aim to set forth the direction and strength of the relationship between tourism and community attachment on the basis of residency duration, birth place, and common heritage (Buzukçu, 2020, p. 54). On the other hand, McCool and Martin (1994, p. 34) reveal that residents with higher community attachment levels have a more positive approach towards tourism whereas residents with lower belonging levels tend to be less positive towards it. As it can be seen, place attachment enables individuals to be more sensitive towards any interventions in the area and to develop environmental approaches and behaviors. Therefore, it is important to examine the relationship between place attachment and tourism in order to develop sustainable tourism policies.

\section{Material and Method}

\section{Sample Selection and Method}

The present study was conducted in ten historical neighborhoods in Central Amasya, which preserve the traditional neighborhood culture and could be considered as the home of some of the best examples of Turkish civil architecture of small squares, Islamic-Ottoman social complexes, and mosques. These neighborhoods are Dere, Fethiye, Hatuniye, Gökmedrese, Sofular, Nergis, Savadiye, Şamlar, Şehirüstü and Üçler. It can be said that the development of tourism is mature in Hatuniye and at start-up phase in the remaining nine neighborhoods.

The universe of the research (the sampling of the study) consists of the households of the ten neighborhoods in 2017 (TÜiK, 2018). Total sample number is determined as 345 for a total of 3336 houses with 95\% confidence interval and \pm 0.05 sampling error. After the total sample was determined, questionnaire size in each neighborhood was determined based on their representation rates in the total pool. The questionnaires were applied between November and December 2017 with simple random sampling method. A total of 460 houses agreed to answer the questionnaire.

\section{Contents of Households Questionnaire Form}

The questionnaire form consists of four sections. The first section contains 15 questions aiming to determine the socio-demographical features of the participants. The second section contains 16 expressions to measure the place attachment of the participants (Göregenli, Karakuş, Özgen Kösten, \& Umuroğlu, 2014, p. 78; Göregenli, 2010, p. 190; Hidalgo \& Hernandez, 2001, p. 277; Yoon, 2002, p. 71; Lewicka, 2005, p. 285). The third section contains 12 expressions to measure the perceived effects of tourism (Yoon, 2002, p. 71) and three expressions to determine the collective effect of tourism (Özaltnn Türker \& Türker, 2014, p. 87). The fourth section of the questionnaire contains 15 expressions to determine the support for tourism (Altanlar, 2015 , p. 436-450). The expressions in the second, third, and fourth sections of the questionnaire are measured based on the five-point Likert Scale (1: Strongly Disagree - 5: Strongly Agree).

\section{Measurement Method and Techniques}

A frequency analysis was conducted to describe the variables on nominal and ordinal levels. In order to determine the construct validity of place attachment and perceived effects of tourism scale, principal components analysis (PCA) was used from exploratory factor analysis; Varimax rotation was used as a vertical rotation method; and Cronbach's Alpha was used to determine consistency. In order to test the normality of scale scores, Shapiro-Wilk Test was used and to discover the relationship between the place attachment scale of the participants and perceived effects of tourism \& the support for tourism scales, "Spearman's correlation" test was applied as a nonparametric test method.

\section{Restrictions of the Study}

Abstract framework of this study was compiled based on the accessible literature resources. In a way, this can be a restriction of the study. Furthermore, another restriction of the study is that there are some variables, which affect the perception and approach of residents towards tourism and which were used in previous studies. Ten traditional neighborhoods in Central Amasya constitute the population of this study. Thus, it must be remembered that the findings of this study cannot be understood as a generalization of historical environments and historical neighborhoods.

\section{Findings}

Results of the Factor Analysis Applied for Place Attachment Attitude Scale

Cronbach's Alpha consistency test was applied in order to determine whether the expressions constituting the place attachment scale are consistent whereas KaiserMeyer-Olkin and Bartlett (KMO) test was applied to test if the sampling size of data structure is suitable for the factor analysis. KMO value was determined as 0.903 . This value shows that sampling size is perfect for factor 
analysis (Çokluk, Şekercioğlu, \& Büyüköztürk, 2012, p. 207). Furthermore, Bartlett's Test of Sphericity results indicate that $x$-square $\left(X^{2}(120)=2491.742 ; p<0.01\right)$ value is meaningful. Since Cronbach's Alpha test value is 0.867 , it can be said that the study is rather consistent and reliable (Table 1).

It was determined that the 16 variables forming the scale based on the principal components analysis applied to show the factor pattern of place attachment scale are gathered under two main components. It was determined that the first component explained the $36.582 \%$ of the total variance and the second component explained $8.004 \%$ of the total variance; and the total variance of the two of was $44.587 \%$. Variance rates changing between $40 \%$ and $60 \%$ are accepted as ideal in social sciences (Çokluk, Şekercioğlu, \& Büyüköztürk, 2012, p. 233).

Conceptualized as "social attachment", the first dimension explained $36.582 \%$ of the total variance and it was determined that the variables had factor loads changing between 0.729 and 0.519 . Reliability coefficient of the factor is 0.818 . Accordingly, the reliability level of this factor is remarkably high. Conceptualized as "the sense of belonging", the second dimension explained $8.004 \%$ of the total variance and it was determined that the variables had factor loads changing between 0.687 and -0.474 . Reliability coefficient of the factor is 0.776 . Accordingly, the reliability level of this factor is high (Table 1).
Because all scores of "social attachment" (S: 0.893; $p=0.000<0.05)$ and "the sense of belonging" ( $S: 0.846$; $\mathrm{p}=0.000<0.05)$ were not indicating normal distribution according to the Shapiro-Wilk test, which tests the normality of scale scores of place attachment approach scale, it was decided to use non-parametric tests for comparative analyses.

Consequently, it is possible to say that attachment to neighborhood is affected by relationships formed with other residents in the neighborhood and the sense of belonging. As well known, the sense of social attachment that defines the social interactions between residents and the sense of belonging formed upon these interactions are inevitably related with the sense of and attachment to community (Göregenli, Karakuş, Özgen Kösten, \& Umuroğlu, 2014, p. 83).

\section{Results of the Factor Analysis Applied for Tourism's}

\section{Perceived Effects Scale}

KMO value of tourism's perceived effects scale is 0.806 , $x$-square is $\left(X^{2}(66)=1580.343 ; p<0.01\right)$ and Cronbach's Alpha value is 0.614 . PCA results determined that the 12 variables forming the scale are gathered under two main components. The first component explains $26.489 \%$ of the total variance whereas the second component explains $21.949 \%$ of the total variance and the total contribution of the two components in the total variance is $48.438 \%$. The first dimension conceptualized as "the positively perceived

Table 1. Factor distribution and reliability analysis results of place attachment scale

\begin{tabular}{|c|c|c|c|c|c|}
\hline Item & $\begin{array}{l}\text { Factor } \\
\text { Load }\end{array}$ & $\begin{array}{c}\text { Explained } \\
\text { Variance Rate }\end{array}$ & $\begin{array}{c}\text { Cronbach's } \\
\text { Alpha }\end{array}$ & $\begin{array}{l}\text { Statistic } \\
\text { (S) }\end{array}$ & $\mathbf{P}$ \\
\hline \multicolumn{6}{|l|}{ Social Attachment } \\
\hline Residents of this neighborhood are fairly connected with each other. & 0.729 & 36.582 & 0.818 & 0.893 & $0.000^{*}$ \\
\hline $\begin{array}{l}\text { Many residents in this neighborhood collaborate with each } \\
\text { other for matters concerning the neighborhood. }\end{array}$ & 0.649 & & & & \\
\hline They defend their neighborhood against critics. & 0.605 & & & & \\
\hline Residents of this neighborhood share similar values. & 0.602 & & & & \\
\hline They love the neighborhood. & 0.601 & & & & \\
\hline Residents of this neighborhood are trustworthy. & 0.598 & & & & \\
\hline They would not engage in any activities concerning the neighborhood. & -0.593 & & & & \\
\hline Residents of this neighborhood usually know one another. & 0.519 & & & & \\
\hline \multicolumn{6}{|l|}{ Sense of Belonging } \\
\hline They feel like they have roots in this neighborhood. & 0.687 & 8.004 & 0.776 & 0.846 & $0.000^{*}$ \\
\hline They have spent their whole lives in this neighborhood. & 0.613 & & & & \\
\hline They feel like they belong to this neighborhood. & 0.613 & & & & \\
\hline They miss the neighborhood when are not around. & 0.611 & & & & \\
\hline They would like to know what is going on in the neighborhood. & 0.602 & & & & \\
\hline They would like to move away. & -0.582 & & & & \\
\hline They feel like a stranger in the neighborhood. & -0.535 & & & & \\
\hline They feel like they are detached from the neighborhood. & -0.474 & & & & \\
\hline
\end{tabular}

If Cronbach's Alpha ( $a$ ) is $\geq 0.9$, the distribution is perfect; if ${ }^{* *} 0.9>a \geq 0.8$ the distribution is fine, if ${ }^{*} 0.8>a \geq 0.7$, it is acceptable. 
Table 2. Factor distribution and reliability analysis results of tourism's effects scale

\begin{tabular}{|c|c|c|c|c|c|}
\hline Tourism's Effects Scale & $\begin{array}{l}\text { Factor } \\
\text { Load }\end{array}$ & $\begin{array}{c}\text { Explained } \\
\text { Variance Rate }\end{array}$ & $\begin{array}{l}\text { Cronbach's } \\
\text { Alpha }\end{array}$ & $\begin{array}{l}\text { Statistic } \\
\text { (S) }\end{array}$ & $\mathbf{P}$ \\
\hline \multicolumn{6}{|l|}{ Tourism's Positively Perceived Effects } \\
\hline Tourism leads to higher standards in road structure and other public activities. & 0.731 & 26.489 & 0.820 & 0.954 & 0.000 \\
\hline Tourism leads to more employment opportunities. & 0.730 & & & & \\
\hline $\begin{array}{l}\text { A development in tourism leads to preservation of the genuineness of } \\
\text { historical structures. }\end{array}$ & 0.716 & & & & \\
\hline Tourism leads to protection of natural resources. & 0.713 & & & & \\
\hline A development in tourism leads to more cultural activities. & 0.706 & & & & \\
\hline A development in tourism enables residents to learn about different cultures. & 0.699 & & & & \\
\hline \multicolumn{6}{|l|}{ Tourism's Negatively Perceived Effects } \\
\hline $\begin{array}{l}\text { Development of tourism leads to disagreements and dissociation } \\
\text { in the neighborhood. }\end{array}$ & 0.701 & 21.949 & 0.733 & 0.980 & 0.000 \\
\hline $\begin{array}{l}\text { Moral values and behaviors of residents are affected negatively } \\
\text { by the development of tourism. }\end{array}$ & 0.688 & & & & \\
\hline $\begin{array}{l}\text { Touristic facilities (hotels, hostels, coffeeshops, etc.) dissolve the genuine } \\
\text { identity of the neighborhood. }\end{array}$ & 0.685 & & & & \\
\hline $\begin{array}{l}\text { A development in tourism dissolves the authentic identity of the } \\
\text { neighborhood. }\end{array}$ & 0.638 & & & & \\
\hline A development in tourism would weaken neighbor relationships. & 0.624 & & & & \\
\hline A development in tourism would destroy the historical environment. & 0.532 & & & & \\
\hline
\end{tabular}

If Cronbach's Alpha ( $a$ ) is $\geq 0.9$, the distribution is perfect; if ${ }^{* *} 0.9>a \geq 0.8$ the distribution is fine, if ${ }^{*} 0.8>a \geq 0.7$, it is acceptable.

effects of tourism" has six items with factor loads between 0.731 and 0.699 . Reliability coefficient of the factor is 0.820 . Accordingly, the reliability level of this factor is remarkably high. Conceptualized as "the negatively perceived effects of tourism", the second dimension consisted of 6 items with factor loads changing between 0.701 and 0.532 . Total variance explanation rate of the factor is $21.949 \%$ and the reliability coefficient is acceptable with a value of 0.733 (Table 2). Because all scores of "tourisms positively perceived effects" ( $S: 0.954 ; p=0.000<0.05$ ) and "tourisms negatively perceived effects" ( $S$ : $0.980 ; p=0.000<0.05$ ) were not indicating normal distribution according to the Shapiro-Wilk test, which tests the normality of scale scores of tourism's perceived effects approach scale, it was decided to use non-parametric tests for comparative analyses.

\section{Defining the Relationship Between Place Attachment Scale and Tourism's Perceived Effects}

Table 3 contains the results of Spearman Correlation Test applied to determine whether there is a linear relationship between the place attachment scale of participants and the positively \& negatively perceived effects of tourism, and if there is, to determine the direction and strength of this relationship. The findings indicate that there is a mid-level positive relationship between the "positively perceived effects of tourism" factor and "social attachment" dimension whereas a weak positive relationship between the "positively perceived effects of tourism" factor and the "sense of belonging" dimension. On the other hand, no relationships were determined between the negatively perceived effects of tourism and place attachment scale (Table 3). The findings indicate that the higher social attachment and sense of belonging levels are, the more participants perceived the positive effects of tourism (or vice-versa). Obtained findings show that social attachment is more effective in the perception of tourism's effects when compared to the sense of belonging.

Table 4 contains the results of Spearman Correlation Test applied to determine whether there is a linear relationship between the place attachment of participants and the cumulative perception of tourism, and if there is, to determine the direction and strength of this relationship. According to Spearman Correlation test findings, it is determined that there is a mid-level positive relationship between the level of participation to "I think tourism is overall beneficial for our neighborhood ( $\overline{\mathrm{X}}$ : 4.2174)" expression and "social attachment" dimension whereas a weak positive relationship between the level of participation to "I think tourism is overall beneficial for our neighborhood" expression and the "sense of belonging" dimension. Similarly, there is a mid-level positive relationship between the level of participation to "I think tourism is overall beneficial for Amasya ( $\overline{\mathrm{X}}$ : 
Table 3. The relationship between place attachment scale and tourism's effects dimensions and the frequency distributions of variables

\begin{tabular}{llcc}
\hline & & Social Attachment & Sense of Belonging \\
\hline Tourism's Positive Effects & Correlation Coefficient $(r)$ & $0.555^{* *}$ & $0.298^{* *}$ \\
& Sig. (2-tailed) & 0.000 & 0.000 \\
Tourism's Negative Effects & $\mathrm{N}$ & 456 & 456 \\
& Correlation Coefficient ( $r)$ & -.086 & -.003 \\
& Sig. (2-tailed) & 0.068 & 0.953 \\
& $\mathrm{~N}$ & 456 & 456 \\
\hline
\end{tabular}

** $p<0.01{ }^{*} p<0.05$ indicates a meaningful relationship, $p>0.05$ indicates there isn't a meaningful relationship

If $r<0.2$, the correlation is too weak; if $0.2<r<0.4$, weak; if $0.4<r<0.6$, midlevel; if $0.6<r<0.8$, high; and if $>0.8$ too high.

Table 4. The relationship between place attachment scale and collective tourism perception levels and the frequency distributions of variables

\begin{tabular}{llcccc}
\hline $\mathbf{n = 4 6 0}$ & & $\begin{array}{c}\text { Social } \\
\text { Attachment }\end{array}$ & $\begin{array}{c}\text { Sense of } \\
\text { Belonging }\end{array}$ & $\begin{array}{c}\text { Mean } \overline{\mathbf{X}} \\
\text { Standard } \\
\text { Deviation }\end{array}$ \\
\hline I think tourism is overall beneficial for our neighborhood. & $r$ & $0.450^{* *}$ & $0.221^{* *}$ & 4.2174 \\
I think tourism is overall beneficial for Amasya. & $p$ & 0.000 & 0.000 & 0.84825 \\
Tourism has more benefits than harm. & $\mathrm{r}$ & $0.487^{* *}$ & $0.182^{* *}$ & 4.4130 & 0.000 \\
& $\mathrm{p}$ & 0.000 & $0.155^{* *}$ & 4.1457 \\
& $\mathrm{r}$ & $0.380^{* *}$ & 0.001 & 0.96026
\end{tabular}

${ }^{* *} p<0.01{ }^{*} p<0.05$ indicates a meaningful relationship, $p>0.05$ indicates there isn't a meaningful relationship

If $\mathrm{r}<0.2$, there is a weak relationship or no correlation; if $0.2-0.4$, there is a weak correlation; if $0.4-0.6$, there is a midlevel correlation; if $0.6-0.8$, there is a high correlation; if $0.8>$, there is a very high correlation.

4.4130)" expression and "social attachment" expression whereas there is a weak positive relationship between the level of participation to "I think tourism is overall beneficial for Amasya" expression and the "sense of belonging" dimension. There is a weak positive relationship between the level of participation to "tourism does more good than harm (X̄: 4.1457)" expression and "social attachment" dimension and the "sense of belonging" dimension.

As a result, the findings show that there is a linear relationship between the place attachment scale and the expressions that constitute the overall approach towards tourism. The more social attachment and belonging the residents feel, the more they agree with the expressions about "tourism will be beneficial for Amasya and its neighborhoods" (or vice-versa). But their approach towards tourism receives a negative impact as soon as any negative effect of touristic activities on the residents' social relationships occurs. Similarly, it is understood that the more social attachment and belonging the participants feel, the more they believe tourism will be beneficial. Both analyses show that social attachment factor has a more significant effect when compared to sense of belonging factor for the perception of tourism's effects.

\section{Defining the Relationship Between Place Attachment} Scale and the Support for Tourism

According to Spearman Correlation test findings, it is determined that there is a mid-level positive relationship between the answers given to "Do you want tourism development in Amasya?" and "Do you want tourism development in your neighborhood?" questions and the "social attachment" dimension whereas a weak positive relationship between the answers to these questions and the "sense of belonging" dimension. Similarly, the answers to these questions have a midlevel positive relationship with the "social attachment" dimension whereas a weak positive relationship with the "sense of belonging" dimension, meaning that the residents support the development of tourism both on city level and neighborhood level (Table 5).

Table 6 contains the results of Spearman Correlation Test applied to determine whether there is a linear relationship between the place attachment scale of participants and the support they will have for touristic activities, and if there is, to determine the direction and strength of this relationship. According to the Spearman Correlation Test: 
Table 5. The relationship between place attachment scale and the overall tourism support on city and neighborhood levels and the frequency distributions of variables

\begin{tabular}{|c|c|c|c|c|c|}
\hline Overall Support for Touristic Activities Scale ( $N=456)$ & & $\begin{array}{c}\text { Social } \\
\text { Attachment }\end{array}$ & $\begin{array}{l}\text { Sense of } \\
\text { Belonging }\end{array}$ & Mean $\bar{X}$ & $\begin{array}{l}\text { Standard } \\
\text { Deviation }\end{array}$ \\
\hline \multirow[t]{2}{*}{ Do you want tourism development in Amasya? } & r & $0.430^{* *}$ & $0.167^{* *}$ & 4.3826 & 060618 \\
\hline & $P$ & 0.000 & 0.000 & & \\
\hline Do you want tourism development in your neighborhood? & r & $0.351^{* *}$ & $0.147^{* *}$ & 4.0935 & 0.95541 \\
\hline (i.e. hotels, restaurants, entertainment venues, etc.) & $P$ & 0.000 & 0.002 & & \\
\hline
\end{tabular}

If $\mathrm{r}<0.2$, there is a weak relationship or no correlation; if $0.4-0.6$, there is a midlevel correlation; if $0.6-0.8$, there is a high correlation; if $0.8>$, there is a very high correlation.

Table 6. The relationship between place attachment scale and tourism support dimensions and the frequency distributions of variables

\begin{tabular}{|c|c|c|c|c|c|}
\hline Participation in and Support for Touristic Activities Scale ( $N=456)$ & & $\begin{array}{c}\text { Social } \\
\text { Attachment }\end{array}$ & $\begin{array}{l}\text { Sense of } \\
\text { Belonging }\end{array}$ & Mean $\bar{X}$ & $\begin{array}{l}\text { Standard } \\
\text { Deviation }\end{array}$ \\
\hline \multirow[t]{2}{*}{ I support the entertainment programs for Tourists. } & $r$ & $0.369^{* *}$ & $0.131^{* *}$ & 4.1739 & 0.75275 \\
\hline & $P$ & 0.000 & 0.005 & & \\
\hline \multirow[t]{2}{*}{ I support the historical and cultural activities for Tourists. } & r & $0.279^{* *}$ & $0.192^{* *}$ & 4.3239 & 0.69033 \\
\hline & $P$ & 0.000 & 0.000 & & \\
\hline \multirow[t]{2}{*}{ I support opening new businesses (hotels, hostels, restaurants) for Tourists. } & $\mathrm{r}$ & $0.379^{* *}$ & $0.168^{* * *}$ & 4.0739 & 0.99398 \\
\hline & $\mathrm{P}$ & 0.000 & 0.000 & & \\
\hline \multirow{2}{*}{$\begin{array}{l}\text { I support the physical changes in the historical structure made to improve } \\
\text { the service quality of touristic hotels, restaurants, etc. }\end{array}$} & $\mathrm{r}$ & $0.357^{* *}$ & $0.217^{* *}$ & 4.1283 & 0.93052 \\
\hline & $P$ & 0.000 & 0.000 & & \\
\hline \multirow[t]{2}{*}{ If tourism is improved, I can rent a part of my house to tourists. } & r & -0.038 & $0.133^{* *}$ & 2.8870 & 1.51112 \\
\hline & $P$ & 0.414 & 0.004 & & \\
\hline \multirow[t]{2}{*}{ I would support my neighbors renting a part of their houses to tourists. } & r & -0.085 & $0.106^{*}$ & 3.0500 & 1.42293 \\
\hline & $P$ & 0.070 & 0.024 & & \\
\hline \multirow[t]{2}{*}{ I would rent my house for businesses like hotels, hostels or restaurants. } & $r$ & 0.020 & 0.049 & 2.9609 & 1.47698 \\
\hline & $P$ & 0.666 & 0.295 & & \\
\hline \multirow{2}{*}{$\begin{array}{l}\text { I support my neighbors to rent their houses for businesses like hotels, } \\
\text { hostels or restaurants. }\end{array}$} & $r$ & -0.010 & 0.058 & 3.1522 & 1.42293 \\
\hline & $P$ & 0.824 & 0.215 & & \\
\hline \multirow{2}{*}{$\begin{array}{l}\text { I would want new independent shops to open in my neighborhood } \\
\text { (gift shops, consultancy services, etc.) }\end{array}$} & $r$ & $0.321^{* *}$ & $0.138^{* *}$ & 4.1291 & 0.94176 \\
\hline & $P$ & 0.000 & 0.003 & & \\
\hline \multirow{2}{*}{$\begin{array}{l}\text { I support cultural and traditional activities in my neighborhood } \\
\text { (concerts, art galleries, handicraft galleries, festivals, etc.). }\end{array}$} & $r$ & $0.363^{* *}$ & $0.102^{*}$ & 4.2609 & 0.80669 \\
\hline & $P$ & 0.000 & 0.029 & & \\
\hline
\end{tabular}

If $\mathrm{r}<0.2$, there is a weak relationship or no correlation; if $0.4-0.6$, there is a midlevel correlation; if $0.6-0.8$, there is a high correlation; if $0.8>$, there is a very high correlation.

- There is a positive but weak relationship between the level of participation to "I support the entertainment programs for Tourists", "I support the historical and cultural activities for Tourists", "I support cultural and traditional activities in my neighborhood", "I support the physical changes in the historical structure made to improve the service quality of touristic hotels, restaurants, etc.", "I would want new independent shops to open in my neighborhood", and "I support opening new businesses (hotels, hostels, restaurants) for Tourists" expressions and "social attachment" \& "sense of belonging" dimensions.

- "Social Attachment" dimension has no relationship with the level of participation to "If tourism is improved, I can rent a part of my house to tourists" and "I would support my neighbors renting a part of their houses to tourists" expressions whereas "sense of belonging" dimension has a positive weak relationship with these expressions.

- There is no relationship between the level of participation to "I would rent my house for businesses like hotels, hostels or restaurants" and "I support my neighbors to rent their houses for businesses like hotels, hostels or restaurants" expressions and "social attachment" \& "sense of belonging" dimensions.

The frequency analysis indicates that the participants were not enthusiastic about renting a part of their houses 
to tourists ( $\overline{\mathrm{X}}: 2.8870)$ and that they are indecisive about their neighbors renting a part of their homes to tourists $(\bar{X}$ : 3.0500). Similarly, the level of agreement to "I would rent my house for businesses like hotels, hostels or restaurants" ( $\bar{X}: 2.9609)$ and "I support my neighbors to rent their houses for businesses like hotels, hostels or restaurants" ( $\bar{X}: 3.1522)$ expressions is fairly low. However, they support the opening of new and independent businesses in their neighborhood ( $\bar{X}:$ 4.1291). These findings indicate that while the residents adopt tourism strategies towards the economic and cultural development of their surroundings, they do not support the strategies that may cause a change in their social and cultural surroundings. This shows that is the social and cultural environment change, the place attachment of residents would decrease.

\section{Discussion and Conclusion}

Historical surroundings are significant for tourism because they act like a bridge between the past and today, and they provide all sorts of hints from the past. However, it wasn't until recently that we understood the development of tourism in historical areas is an all-around process and the residents and local entrepreneurs must be included in this process. Within this framework, it is clear that we need tourism policies and strategies applied in these areas to be more independent from an economic point of view and be more focused on social, cultural, and educational dimensions in order to ensure a healthy preservation and utilization of historical areas.

This study examined the tourism approach and the support for tourism of residents based on their place attachment. According to the study results, it was determined that place-based sense of belonging and social attachment had an influence on the residents' perception of and approach towards tourism. It is seen that neighborhood residents were in agreement that tourism would have positive effects on the neighborhood and that they did not develop any concerns about any negative effects of tourism. However, it is significant at this point to consider that tourism development in nine of the sample neighborhoods is merely beginning and in one sample neighborhood, it is almost mature. There is a linear relationship between the place attachment of residents and their support for tourism. Similarly, it is understood that the more place attachment and sense of belonging the residents feel, the more supportive and participative they are of touristic ventures. This also indicates that any negative developments that may arise with functional changes that comes with touristic endeavors might cause a negative impact on their approach to and support of tourism.

The need to be away from criminal activities rising with the development of tourism and live in a peaceful and safe environment might cause residents to leave their all place-related experiences and memories behind and move away. Despite having all the opportunities regarding a physical environment, individuals tend to feel unhappy and constantly anxious if they feel insecure, which weakens their attachment with the place. Furthermore, it is seen that an individual feeling insecure and afraid of criminal activities tends to detach from social life and have decreasing neighborly relationships. This eventually causes a weakening of social and cultural relationships in the region, a decrease in the sense of belonging the residents feel, and the withering of communal memory. For this reason, determining and understanding the factors that influence the support of residents and/or local communities is crucial for the planners and the success of any plan or project regarding the development of tourism. Information about the factors influencing the support of residents and the mutual interactions of these factors can help planners and entrepreneurs measure the support for any venture beforehand. If the likelihood of residents supporting the suggested development project is low, it is possible that the project will face a strong opposition to almost ensure its failure. Conceptual measurement models of place attachment and support for tourism created for this study may help planners to determine the likelihood of residents supporting a suggested project.

The results of this study show that planners must evaluate the residents' anxiety levels about the community, their approach and attitude towards the development of tourism, their tendencies, and local economic status before suggesting a project to develop tourism. A tourism development plan will be supported only as much as the level of attachment residents feel towards their social surroundings and neighborhoods. For this reason, planners and businesses must focus on the factors the residents care deeply about (environment, economic welfare of the community, recreation, culture, etc.), must explain how the development of tourism will help in preserving these factors and encourage residents about these subjects. Within that concept, including the residents in the planning process, informing them about the potential benefits of tourism, encouraging them for local touristic ventures, and supporting them in doing so may help ensure the participation that is essential for a successful and sustainable operation.

\section{References}

Altanlar, A. (2015). A Conceptual Model And A Method For The Measurement Of Cultural tourism Development Capacity: The Case Of Bosphorus, İstanbul. İstanbul: Yıldız Technical University Urban Planning Doctorate Program.Unpublished Doctoral Thesis. 
Arslan Ayazlar, R., \& Ayazlar, G. (2016). The Role of Sense of Belonging and Life Satisfaction on Local People's Attitude towards Tourism Effects. Atatürk Üniversitesi Sosyal Bilimler Enstitüsü Dergisi, 20(4): 1451-1470.

Aytaç, Ö. (2013). Urban Spacesand Identity/Difference Problem. İdealkent, 138-169.

Bolzoni, M. (2013). What Tourists Ignore Ambivalences, Conflicts and Compromises in A Changing Neighbourhood. The International RC21 Conference 2013- Session: Resistance and Protest in the Tourist City. Berlin.

Bolzoni, M. (2014). Turning to leisure and entertainment inTimeof Crisis. Atlantis, 10-14.

Brown, B., Perkins, D. D., \& Brown, G. (2003). Place attachment in a revitalizing neighborhood: Individual and block levels of analysis. Journal of Environmental Psychology, 259-271.

Brown, B., Perkins, D., \& Brown, G. (2004). Incivilities, place attachment and crime: Block and individual effects. Journal of Environmental Psychology, 24 (2004) 359-371.

Buzukçu, C. (2020). The Relationship Between Resident's Place Identity, Community Attachment, Sustainable Toruism Attitude Support For Toruism Development And Life Satisfaction. Unpublished Doctoral Thesis, Balıkesir University Institute of Social Sciences, Departman of Toruism Management, Balıkesir.

Choi, H., \& Murray, I. (2010). Resident Attitudes Toward Sustainable Community. Journal of Sustainable Tourism, 18(4), 575594.

Çokluk, Ö., Şekercioğlu,. G., \& Büyüköztürk, Ş. (2012). Sosyal Bilimler için Çok Değişkenli İstatistik: SPSS ve LISTER Uygulamaları,. Pegem Akademi: Ankara.

Ginting, N., \& Wahid, J. (2016). Defining distinctiveness aspect of place identity in urban heritage tourism. 8th International Conference on Architecture Research and Design (AR+DC). Indonesia: $A R+D C$.

Göregenli, M. (2010). Çevre Psikolojisi İnsan Mekan iliş̧kileri. İstanbul: Bilgi Üniversitesi Yayınları.

Göregenli, M., Karakuş, P., Özgen Kösten, Y. E., \& Umuroğlu, İ. (2014). Neighborhood Commitment Level Investigation in Urban Relationship. Turkish Journal of Psychology, 73-85.

Hallak, R., Brown, G., \& Lindsay, J. (2012). The Place Identity e Performance relationship among tourism entrepreneurs: A structural equation modelling analysis. Tourism Management, 143-154.

Hernandez, B., Martin, M., Ruiz, C., \& Hidalgo, M. (2010). The role of place identity and place attachment in breaking environmental protection laes. Journal of Environmental Psychology, 30:281-288.

Hernandeza, B., Hidalgo, M. C., Salazar-Laplace, M., \& Hes, S. (2007). Place attachment and place identity in natives and non-natives. Journal of Environmental Psychology, 310-319.

Hidalgo, C. M., \& Hernandez, B. (2001). Place Attachment: Conceptual And Empirical Questions. Journal of Environmental Psychology, 273-281.
Huning, S., \& Novy, J. (2006). Tourism as an Engine of Neighborhood Regeneration?Some Remarks Towards a Better Understanding of Urban tourism beyond the 'Beaten Path'. CMS Working Paper Series, 1-18.

Ilgın, C., \& Hacıhasanoğlu, O. (2006). A model for migration - attachment relations: example Berlin/ Kreuzberg. itüdergisi/a mimarlık, planlama, tasarım, 5(1):59-70.

Kozak, N., Kozak, M., \& Kozak, M. (2013). Genel Turizm Illkeler Kavramlar. Ankara: Detay Yayıncılık.

Kunzmann, K. (2004). Culture, Creativity And Spatial Planning. TPR, 75(4): 383-404.

Kyle, G., Graefe, A., Manning, R., \& Bacon, J. (2014). Effects of place attachment on users' perceptions of social and environmental conditions in a natural setting. Journal of Environmental Psychology, 24 (2004) 213-225.

Lewicka, M. (2005). Ways to make people active: The role of place attachment, cultural capita, and neighborhood ties. Journal of Environmental Psychology, 381-395.

Lewicka, M. (2008). Place attachment, place identity, and place memory: Restoring The Forgotten City Past. Journal of Environmental Psychology, 28: 209-231.

McCool, S., \& Martin, S. (1994). Community Attachment and Attitudes Toward Tourism Development. Journal of Travel Research, 29-34.

Özaltin Türker, G., \& Türker, A. (2014). How Effect's The Local Residents Perception of Toursim Impact Level To The Toruism. Electronic Journal of Vocational Colleges, 81-98.

Rollero, C., \& Piccoli, N. (2010). Place attachment, identification and environment perception: An empirical study. Journal of Environmental Psychology, 198-205.

Stylidis, D. (2018). Place Attachment, Perception of Place and Residents' Support for Tourism Development. Tourism Planning \& Development, 1-23.

TÜiK. (2018, 08 10). Population Registration System.

Wang, S., \& Chen, J. (2015). The influence of place identity on perceived place identity on perceived. Annals of Toursim Research, 52:16-28.

Wang, S., \& Xu, H. (2015). Influence of place-based senses of distinctiveness, continuity, selfesteem and self-efficacy on residents' attitudes toward tourism. Tourism Management, 47: 241-250.

Vorkin, M., \& Reise, H. (2001). Environmental Concern in a Local Context the Significance of Place Attachment. Environment and Behavior, 33: 249-263.

Yılmaz Çakmak, B. (2013). The Example of a Re-Use in the Context of Cultural Heritage Conservation, Hamdi Gültepe House. Artium, 1(1):1-12.

Yoon, Y. (2002). Development of a Structural Model for Tourism Destination Competitiveness from Stakeholders' Perspectives. Virginia: Faculty of The Virginia Polytechnic Institute and State University In Partial Fulfillment of The Requirement for The Degree of Doctor of Phılosophy. 